\title{
Tiotropium InCREASES CyTOSOLIC MusCARINIC M3 RECEPTORS AND Acetylated H3 Histone Proteins in Induced Sputum Cells OF COPD PATIENTS
}

\author{
A. Holownia ${ }^{1}$, R. M. Mroz ${ }^{2}$, T. Skopinski ${ }^{1}$, A. Kielek ${ }^{1}$, A. Kolodziejczyk ${ }^{1}$, E. Chyczewska², J. J. Braszko ${ }^{1}$ \\ ${ }^{1}$ Department of Clinical Pharmacology and ${ }^{2}$ Department of Chest Diseases and Tuberculosis, \\ Bialystok Medical University, Bialystok, Poland
}

\begin{abstract}
Objective: Chronic obstructive pulmonary disease (COPD) is characterized by irreversible progressive airflow limitation related to tobacco smoking. This limitation is caused by chronic inflammation of the airways and lung parenchyma and is associated with increased activity of parasympathetic system. The most effective bronchodilators in COPD are muscarinic receptor antagonists (MRA), which reverse, at least in part, compromised respiratory function. MRA also contribute to control inflammatory processes via interactions with inflammatory signaling molecules. The use of the longacting cholinolytic bronchodilatator - tiotropium, with high affinity to M3 receptors, is suggested as a first line maintenance treatment in COPD patients.

Material and methods: In this study we assessed M3 receptor protein expression in induced sputum of 27 stable COPD patients before and after therapy consisting of $18 \mu \mathrm{g}$ once daily tiotropium for 12 weeks. Lung function tests including spirometry, lung volumes, and DLCO were performed before and after therapy in all COPD patients. The patients were subjected to the sputum induction procedures before and after therapy. Sputum cells were isolated, sample-specific cell profiles were characterized, and the cells were processed to isolate pure cytosolic fractions. Cytosolic M3 protein and HDAC2 levels and nuclear acetylated histone $\mathrm{H} 3$ (AcH3) expression was quantified using specific antibodies against human proteins and Western blot with enhanced luminescence detection.

Results: Therapy significantly increased the mean forced expiratory volume in one second (FEV1) and forced vital capacity (FVC) volume $(\mathrm{P}<0.05)$. The mean expression of M3 protein was higher by $37 \%$ after therapy $(\mathrm{P}<0.05)$, HDAC2 expression was not altered, while AcH3 level was increased by about 90\% $(\mathrm{P}<0.01)$, compared with the corresponding data before therapy. HDAC2 expression before therapy was positively correlated with $\mathrm{AcH} 3$ expression $(\mathrm{r}=0.74)$, while after therapy no correlation was detected. FEV1, FCV, and cytosolic M3 protein expression did not correlate with other biochemical parameters tested.

Conclusions: Twelve weeks of tiotropium therapy in COPD patients improves clinical indices of lung function and involves alterations in sputum cell chromatin acetylation and also increased cholinergic M3 receptor internalization.
\end{abstract}

Key words: COPD, chromatin, histone acetylation, M3 receptors, tiotropium

\section{INTRODUCTION}

Chronic obstructive pulmonary disease (COPD) is characterized by irreversible but progressive airflow limitation. This limitation is caused by chronic inflammation of the airways and lung parenchyma which is related to tobacco smoking, and is associated with increased activity of parasympathetic system [1]. The most effective bronchodilators in COPD are muscarinic receptor antagonists (MRA), which reverse, at least in part, compromised respiratory function $[1,2]$. MRA also contribute to control inflammatory processes via interactions with inflammatory signaling molecules [3]. Once daily use of the long acting cholinolytic bronchodilatator tiotropium, with high affinity to M3 receptors, is suggested as a first line maintenance treatment in COPD patients [2].

Chromatin remodeling is related to gene regulation and acetylation of the histone tail correlates with its transcriptional activity [4]. Histone hyperacetylation increases chromatin-mediated transcription and inversely, its hypoacetylation results in condensation of nucleosomes and indicates gene repression. Both states are controlled by a dynamic interplay of histone acetyltransferases (HATs) and histone deacetylases (HDACs) [5], and graded reductions in HDAC activity and expression were observed in lung tissue of $\mathrm{pa}-$ tients with increasing clinical stages of COPD $[5,6]$. Such epigenetic mechanisms are modifiable by several drugs, but there are only scarce data on the acquisition of a specific intracellular transmitter system in histone signaling. Nicotine was found to induce chromatin decondensation and histone $\mathrm{H} 3$ acetylation and this increase was inhibited by nicotinic receptor antagonist [7], suggesting that nicotine alters cellular function directly via nicotinic acetylcholine receptors. However, the role of cholinolytics in chromatin signaling is still obscure. Recent data indicate that muscarinic receptors are implicated in the regulation of inflammation in COPD patients [3].

The aim of the present study was to assess histone acetylation status and intracellular M3 receptor levels in sputum cells of stable COPD patients before and after tiotropium therapy. 


\section{Material And Methods}

\section{SUBJECTS}

All patients included in the study gave their consent after a full discussion of the nature of the study, which had been approved by a local Ethics Committee.

Sputum was induced in 27 COPD patients with stable disease, defined according to Global Initiative for Chronic Obstructive Lung Disease (GOLD) guidelines [8]. All patients had airflow limitation (FEV1 <80\% predicted, FEV1/FVC $<70 \%$, GOLD stage 2-2) and received no COPD therapy for four weeks. All subjects were characterized with respect to sex, age, smoking history, COPD symptoms, comorbidity, and current medical treatment. Exclusion criteria included the following: other systemic diseases, other lung diseases apart from COPD and lung tumors, pulmonary infection and antibiotic treatment $4 \mathrm{wk}$ before inclusion, or inhaled and oral glucocorticosteroids in the 3 months before inclusion. No patient in the study had symptoms nor was treated for COPD exacerbation during at least two months proceeding the day of inclusion.

\section{TREATMENT AND SPIROMETRY}

All patients underwent a 4-wk washout with Salbutamol only on demand therapy and then they were treated with $18 \mu \mathrm{g}$ tiotropium once daily, for 12 weeks. Sputum induction was performed before and after therapy.

The lung function and DLCO tests were performed with body box (Elite DL, Medgraphics, USA). The measurement was performed using standard protocols according to American Thoracic Society guidelines.

\section{Sputum Induction AND Processing}

Sputum was induced by the inhalation of a $4.5 \%$ hypertonic aerosol saline solution, which was generated by an ultrasonic nebulizer (Voyager, Secura Nova; Warsaw, Poland) [9]. Samples were processed within 15 min after termination of induction. Throughout the procedure, subjects were encouraged to cough and to expectorate into a plastic container. Three flow volume curves were performed before and after each inhalation, and the best FEV1 was recorded. Induction of sputum was stopped if the FEV1 value fell by at least $20 \%$ from baseline or if troublesome symptoms occurred.

Induced sputum samples were solubilized in an equal volume of $0.1 \%$ dithiotreitol (Sigma Chemicals, Poznan, Poland) in Hanks solution and incubated for $15 \mathrm{~min}$ in an ice bath. Cell suspension was then rinsed twice with Hanks solution, filtered by a nylon membrane and centrifuged (1000 rpm) on Histopaque 1077. Isolated cell pellets subjected to homogenization and subsequent differential centrifugation to isolate cytosolic and nuclear fractions.

To isolate subcellular fractions, sputum cells were centrifuged, resuspended in cold hypotonic buffer containing $10 \mathrm{mM}$ HEPES, pH 7.9, $1.5 \mathrm{mM} \mathrm{MgCl}_{2}, 10$ $\mathrm{mM} \mathrm{KCl}, 50 \mathrm{mM}$ dithiothreitol, $100 \mathrm{mM}$ phenanthroline, $1 \mathrm{mg} / \mathrm{ml}$ pepstatin, $100 \mathrm{mM}$ trans-epoxysuccinylL-leucylamido-(4-guanidino)butane, $100 \mathrm{mM} \mathrm{3,4-}$ dichloroisocoumarin, $10 \mathrm{mM} \mathrm{NaF}, 100 \mathrm{mM}$ sodium orthovanadate, $25 \mathrm{mM}$ b-glycerophosphate and centrifuged at $14,000 \mathrm{xg}$ for $5 \mathrm{~min}$ at $4^{\circ} \mathrm{C}$ [10]. Cells were then lysed in a solution of the same buffer containing $0.2 \%(\mathrm{v} / \mathrm{v})$ Nonidet P- 40 for $10 \mathrm{~min}$ on ice and centrifuged at $14000 \times \mathrm{g}$ for $10 \mathrm{~min}$ at $4{ }^{\circ} \mathrm{C}$. The supernatant was then collected as a cytosolic extract. The remaining pellet was resuspended in extraction buffer (20 mM HEPES, pH 7.9, $420 \mathrm{mM} \mathrm{NaCl}, 1.5 \mathrm{mM}$ $\mathrm{MgCl}_{2}, 0.2 \mathrm{mM}$ EDTA, 25\% (v/v) glycerol, $100 \mathrm{mM}$ 3,4-dichloroisocoumarin), incubated for $15 \mathrm{~min}$ at $4^{\circ} \mathrm{C}$, and centrifuged at $14000 \times \mathrm{g}$ for $10 \mathrm{~min}$ at $4^{\circ} \mathrm{C}$. The supernatant including soluble nuclear protein was collected as a nuclear extract.

Acid extraction of histones was performed in nuclear fractions using hydrochloric acid $(0.2 \mathrm{M}$ final concentration) and centrifugation $(11000 \times \mathrm{x}$ for 10 min at $4^{\circ} \mathrm{C}$ ) [11]. Supernatant containing acid-soluble proteins was dialyzed for $1 \mathrm{~h}$ against $\mathrm{M}$ acetic acid and then was used to histone expression assays.

The cytosolic fractions were evaluated for the expression of M3 receptor proteins and HDAC2 while histone extract were assessed for acetylated H3 levels using sodium dodecyl sulfate - polyacrylamide-gel electrophoresis (SDS-PAGE) and Western blots. Sample proteins were separated in reducing conditions, transferred onto polyvinylidene difluoride (PVDF) membranes, and incubated with specific rabbit monoclonal antibodies against human M3 (Abcam, Cambridge, USA). After washing, bound antibody was detected using appropriate secondary anti-rabbit antibody (Abcam, Cambridge, USA) linked to horseradish peroxidase. The bound complexes were detected using enhanced chemiluminescence (ECL, Amersham, GE Healthcare, Little Chalfont, UK) and quantified using Image Quant software. The constitutively expressed protein, $\beta$-actin, served as a loading control and the data were quantified in respect to $\beta$-actin expression.

To estimate expression of acetylated H3 levels, extracted histone proteins were separated along with molecular weight markers (Bio-Rad, Hercules, CA, USA) in $20 \%$ polyacrylamide SDS gels while other proteins were run on $10 \%$ SDS gels. Gels were transferred onto $0.45 \mu \mathrm{m}$ PVDF membranes (BioRad, Warsaw, Poland). For the negative control study, membranes were treated similarly but without the addition of primary antibody. Species-specific horseradish peroxidase secondary antibodies were purchased from Abcam (Abcam Inc, Cambridge, USA). Gels were checked for loading using Coomassie staining. Protein bands were quantified using Quantity One software (BioRad, Warsaw, Poland).

Protein levels were measured using a BCA kit (Sigma-Aldrich, Poznan, Poland).

The data are expressed as means \pm SD. Statistical significance was calculated using one-way analysis of variance (ANOVA) followed by the Bonferroni posthoc test for selected pairs of data. For correlation analysis, statistical package Statistica (Statsoft, Cracow, Poland) was used.

\section{RESULTS}

Table 1 and Figure 1 show cytosolic M3 protein, cytosolic HDAC2, and nuclear acetylated histone $\mathrm{H} 3$ 


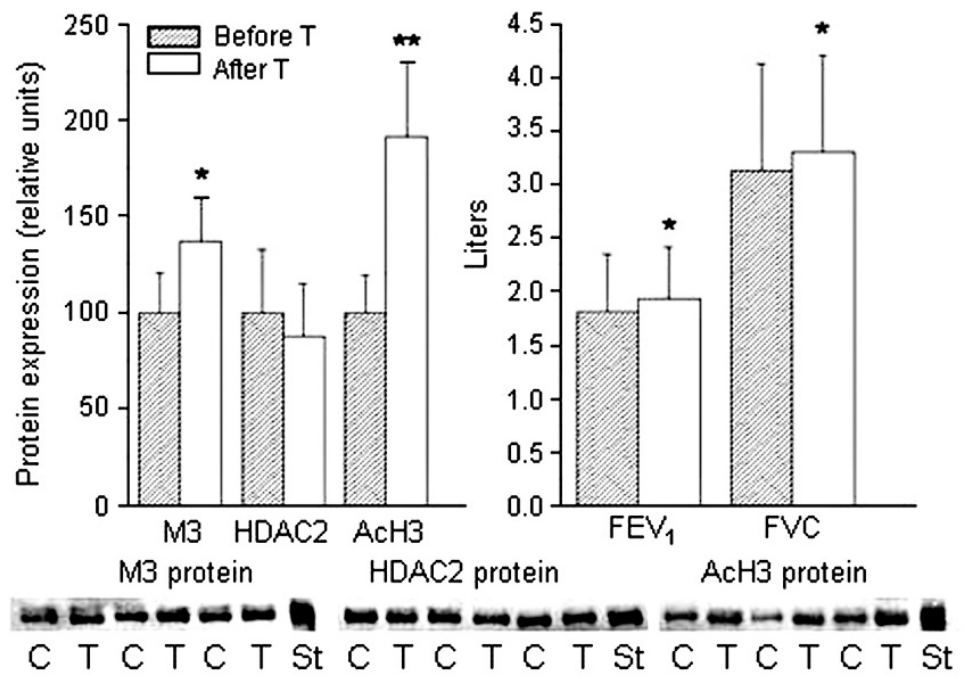

Fig. 1. Relative cytosolic M3 and HDAC2 expressions and nuclear acetylated histone $\mathrm{H} 3(\mathrm{AcH} 3)$ protein in cells isolated from induced sputum of COPD patients before and after 12 weeks of tiotropium ( $\mathrm{T}$ ) therapy. Representative Western blot pictures of $\mathrm{M} 3, \mathrm{HDAC} 2$, and $\mathrm{AcH} 3$ proteins are also shown. $\mathrm{C}$ - untreated patient; $\mathrm{T}$ - the same patient after $\mathrm{T}$ therapy; $\mathrm{St}-$ standard protein.
Table 1. Relative content of cytosolic protein levels in cells isolated from induced sputum and spirometric indices in COPD patients before and after tiotropium therapy.

\begin{tabular}{ccc}
\hline & Before therapy & After therapy \\
\hline M3 & $100.0 \pm 21.3$ & $137.6 \pm 22.5^{*}$ \\
HDAC2 & $100.0 \pm 33.2$ & $88.1 \pm 27.1$ \\
AcH3 & $100.0 \pm 19.8$ & $191.6 \pm 38.8^{* *}$ \\
FEV1 & $1.8 \pm 0.5$ & $1.9 \pm 0.5^{*}$ \\
FVC & $3.1 \pm 1.0$ & $3.3 \pm 0.9^{*}$ \\
\hline
\end{tabular}

Expressions of specific proteins were equalized in each sample for loading and numerized with density software (GelDocXR, BioRad, Warsaw, Poland). The mean protein expression before therapy was set as 100 relative units. $* \mathrm{P}<0.05$ and $* * \mathrm{P}<0.01$ compared with the corresponding data before therapy.

protein levels in cells isolated from induced sputum of COPD patients before and after tiotropium therapy. The mean FEV1 and FVC values are also shown. After therapy, the mean expression of M3 protein was higher by 37\%, ( $<<0.05)$, HDAC2 expression was not altered while $\mathrm{AcH} 3$ levels increased by about $90 \%$ $(\mathrm{P}<0.01)$, compared with the corresponding data before therapy. The correlation analysis showed no relationship between cytosolic M3 receptor expression and any other parameters tested. HDAC2 expression before therapy was positively correlated with $\mathrm{AcH} 3$ $(r=0.74)$ while after therapy no such correlation was observed $(r=0.06)$. Therapy resulted in improved clinical status of the patients and increased their individual FEV1 $(\mathrm{P}<0.05)$ and FVC $(\mathrm{P}<0.05)$ values. Both clinical indices of lung function did not correlate with biochemical parameters tested.

\section{DISCUSSION}

Tiotropium is a new synthetic muscarinic receptor inhibitor, structurally related to ipratropium, but with slower dissociation and higher receptor affinity $[2,12]$. Drug binding to M3 and M1 muscarinic receptors produces prolonged improvement in clinical respiratory parameters just after a single inhaled dose [9, 13, 14]. Apart from significant bronchodilatory activity of the drug, it was recently reported that tiotropium reduced inflammation in COPD patients [3, 15], and in experimental animals [16], but antiinflammatory mechanisms of tiotropium are unknown.

Reversible acetylation and deacetylation of histone proteins is essential to the regulation of inflammatory response of the cells at the nuclear level [4]. Epigenetic changes in chromatin are important in many inflammatory diseases including COPD, because the disease severity correlates with reduction in total HDAC activity, histone acetylation levels, and with IL-8 production [17]. In asthma, bronchial tissue and alveolar macrophages also have increased HAT and decreased HDAC1 expression [18]. In this study, we examined two aspects relevant to inflammatory signaling in sputum cells of COPD patients before and after tiotropium therapy; the first - chromatin acetylation status and the second - cytosolic levels of M3 muscarinic receptor subtype which may be relevant to chronic inflammation and patient's response to anticholinergics.

Our data show that after tiotropium therapy, expression of HDAC2 protein in sputum cells is not altered while AcH3 levels are highly elevated compared with the corresponding data before therapy. Moreover, a positive correlation between HDAC2 expression and $\mathrm{AcH} 3$ levels was detected before, but not after, therapy. It seems that a significant increase in $\mathrm{AcH} 3$ may be related to persistent reduced HDAC activity secondary to stress and inflammation, as has been reported in COPD patients [19]. Such alteration seems to act in favor of increased proinflammatory signaling; however, patients FEV1 and FVC values after therapy were significantly improved. We have previously described increased HAT-related signaling in COPD patients subjected to formoterol and glucocorticosteroid therapy [11]. It should be stressed that HATs and HDACs are not acting in biological systems as simple activating/repressing switches. The major inflammatory transcription factor - NFKB requires sequential acetylation and deacetylation to be stabilized and activated [20]. Also, high HDAC activity is usually considered as protective, but at the same time, HDAC inhibitors are very efficient anti-inflammatory agents [21, 22]. In- 
creased $\mathrm{AcH}$ in sputum cells of COPD patients after tiotropium therapy indicates a possible involvement of chromatin acetylation in tiotropium effect. However, further studies, especially involving HDAC functional assays, are needed to characterize the role of chromatin in inflammatory changes in COPD patients.

Higher cytosolic M3 protein levels after 12 weeks of tiotropium indicate that sputum cells may increase internalized receptor proteins. It has already been reported that the expression of membrane-bound muscarinic M3 receptors on sputum macrophages is significantly increased in COPD patients [23]. This aspect may be important not only for alterations in cholinergic signaling, but also for local inflammation, since acetylcholine has been found in airway nerves, smooth muscle cells, lymphocytes, and macrophages [3, 23]. Functional studies show that acetylcholine induces the release of leukotriene B4, activates the p42/p44 MAP kinase pathway in sputum cells from COPD patients, and induces neutrophilic chemotactic activity [24]. Thus, it seems that actylcholine may regulate lymphocyte proliferation and cytokine release in COPD, resulting in alterations in airway inflammation. However, the precise functional impact of dynamic receptor expression on these cells needs to be elucidated. Our data clearly show that tiotropium therapy involves pharmacodynamic changes in cholinergic M3 receptors and alterations in chromatin acetylation in inflammatory cells migrating to the airways of COPD patients.

Conflicts of interest: The authors had no conflicts of interest to declare in relation to this article.

\section{REFERENCES}

1. Viegi G, Pistelli F, Sherrill DL, Maio S, Baldacci S, Carrozzi L. Definition, epidemiology and natural history of COPD. Eur Respir J 2007; 30: 993-1013.

2. Mamary AJ, Criner GJ. Tiotropium bromide for chronic obstructive pulmonary disease. Expert Rev Respir Med 2009; 3: 211-20.

3. Profita M, Giorgi RD, Sala A, Bonanno A, Riccobono L, Mirabella F, Gjomarkaj M, Bonsignore G, Bousquet J, Vignola AM. Muscarinic receptors, leukotriene B4 production and neutrophilic inflammation in COPD patients. Allergy 2005; 60: 1361-9.

4. Khan SN, Khan AU. Role of histone acetylation in cell physiology and diseases: An update. Clin Chim Acta 2010; 411: 1401-11.

5. Barnes PJ. Histone deacetylase-2 and airway disease. Ther Adv Respir Dis 2009; 3: 235-43.

6. Mroz RM, Holownia A, Chyczewska E, Braszko JJ. Chronic obstructive pulmonary disease: an update on nuclear signaling related to inflammation and anti-inflammatory treatment. J Physiol Pharmacol 2008; 59 Suppl 6: 3542.

7. Landais E, El-Khoury V, Prevost A, Dufer J, LiautaudRoger F. Nicotine induces chromatin changes and c-Jun up-regulation in HL-60 leukemia cells. Oncol Rep 2005; 14: $1553-8$.

8. From the Global Strategy for the Diagnosis, Management and Prevention of COPD, Global Initiative for Chronic Obstructive Lung Disease (GOLD) 2008. Available from: http://www.goldcopd.org.

9. Loh LC, Kanabar V, D'Amato M, Barnes NC, O'Connor BJ. Sputum induction in corticosteroid-dependant asthmatics: risks and airway cellular profile. Asian Pac J Allergy Immunol 2005; 23: 189-96.
10. Mroz RM, Holownia A, Chyczewska E, Drost EM, Braszko JJ, Noparlik J, Donaldson K, Macnee W. Cytoplasm-nuclear trafficking of CREB and CREB phosphorylation at Ser133 during therapy of chronic obstructive pulmonary disease. J Physiol Pharmacol 2007; 58 Suppl 5: 437-44.

11. Holownia A, Mroz RM, Noparlik J, Chyczewska E, Braszko JJ. Expression of CREB-binding protein and peroxisome proliferator-activated receptor gamma during formoterol or formoterol and corticosteroid therapy of chronic obstructive pulmonary disease. J Physiol Pharmacol 2008; 59 Suppl 6: 303-9.

12. Dowling MR, Charlton SJ. Quantifying the association and dissociation rates of unlabelled antagonists at the muscarinic M3 receptor. Br J Pharmacol 2006; 148: $927-$ 37.

13. Hansel TT, Barnes PJ. Tiotropium bromide: a novel oncedaily anticholinergic bronchodilator for the treatment of COPD. Drugs Today 2002; 38: 585-600.

14. Kato M, Komamura K, Kitakaze M. Tiotropium, a novel muscarinic M3 receptor antagonist, improved symptoms of chronic obstructive pulmonary disease complicated by chronic heart failure. Circ J 2006; 70: 1658-60.

15. Perng DW, Tao CW, Su KC, Tsai CC, Liu LY, Lee YC. Anti-inflammatory effects of salmeterol/fluticasone, tiotropium/fluticasone or tiotropium in COPD. Eur Respir J 2009; 33: 778-84.

16. Wollin L, Pieper MP. Tiotropium bromide exerts anti-inflammatory activity in a cigarette smoke mouse model of COPD. Pulm Pharmacol Ther 2010; 23: 345-54.

17. Ito K, Ito M, Elliott WM, Cosio B, Caramori G, Kon OM, Barczyk A, Hayashi S, Adcock IM, Hogg JC, Barnes PJ. Decreased histone deacetylase activity in chronic obstructive pulmonary disease. N Engl J Med 2005; 352: 1967-76.

18. Grabiec AM, Tak PP, Reedquist KA. Targeting histone deacetylase activity in rheumatoid arthritis and asthma as prototypes of inflammatory disease: Should we keep our HATs on? Arthritis Res Ther 2008; 10: 226.

19. Barnes PJ. Histone deacetylase-2 and airway disease. Ther Adv Respir Dis 2009; 3: 235-43.

20. Quivy V, Van Lint C. Regulation at multiple levels of NFkappaB-mediated transactivation by protein acetylation. Biochem Pharmacol 2004; 68: 1221-9.

21. Copeland RA, Olhava EJ, Scott MP. Targeting epigenetic enzymes for drug discovery. Curr Opin Chem Biol 2010; 14: 505-10.

22. Dinarello CA. Anti-inflammatory Agents: Present and Future. Cell 2010; 140(6): 935-50.

23. Gosens R, Zaagsma J, Meurs H, Halayko AJ. Muscarinic receptor signaling in the pathophysiology of asthma and COPD. Respir Res 2006, 7: 73-88.

24. Wessler IK, Kirkpatrick CJ. The non-neuronal cholinergic system: an emerging drug target in the airways. Pulm Pharmacol Ther 2001; 14: 423-34.

Address for correspondence:

Adam Holownia

Department of Clinical Pharmacology

Medical University of Bialystok

15A, Waszyngtona St.

15-279 Bialystok

Poland

Phone/fax: +48 857450647

E-mail: holow_sinai@hotmail.com 